\title{
Good Governance in Bangladesh: A Quest for a Non-Political Party
}

\author{
Approach \\ Sayed Javed Ahmad \\ Civil Service College, University of Dhaka \\ 63 New Eskaton, Dhaka-1000, Bangladesh \\ Tel: 88-019-1100-8853Ｅ-mail: javedahmad@yahoo.com
}

\begin{abstract}
This paper discusses the problems and issues on the political failures in Bangladesh and seeks to suggest some possible solutions. The approach here is analytical mostly reviewing current news, reports and other related materials. A comparative study is also carried out between the present and proposed system to get a quick glimpse on the overall situation. The idea here is to identify reasonable and practical solutions that would yield better result for Bangladesh and bring about positive changes in the political scenario that would allow the country to move forward as a successful and dignified nation. The author has kept the scope of this paper limited to political party, elections, governance and constitutional reforms.

A great deal of references is used in the thesis from the Constitution of Bangladesh as it is the highest source of guidance for our government. While doing so, some weaknesses of the constitution have been detected and some corrections are suggested where deemed appropriate. Examples of some gross violation of the constitution by the political party based government have also been discussed.
\end{abstract}

Keywords: Politics, Good Governance, Economics, Bureaucracy, Corruption

\section{Introduction}

Since its emergence as an independent state, Bangladesh has not been very successful with democracy. The nation have repeatedly stumbled with the political system and had to confront chaos at different intervals. This gives us an indication that we must be doing something very wrong for which we continue to fail in our struggle to achieve a peaceful democracy.

The government is expected to be good. But now a day we have a buzz word "Good Governance" to separate the "Bad Governance" under some criteria. So what is "Good Governance"? The terms "governance" and "good governance" are increasingly being used in development literature. According to Wikipedia - the free online encyclopedia, governance is described as the process of decision-making and the process by which decisions are implemented (or not implemented). Hereby, public institutions conduct public affairs, manage public resources, and guarantee the realization of human rights. Good governance accomplishes this in a manner essentially free of abuse and corruption, and with due regard for the rule of law.

As per United Nations Economic and Social Commission for Asia and the Pacific (UNESCAP), good governance has eight major characteristics. It is participatory, consensus oriented, accountable, transparent, responsive, effective and efficient, equitable and inclusive and follows the rule of law. It assures that corruption is minimized, the views of minorities are taken into account and that the voices of the most vulnerable in society are heard in decision-making. It is also responsive to the present and future needs of society.

This thesis is the ultimate outcome of the understanding of the problem resulted in an attempt to show a way out from this political mess. According to author's judgment, the root cause of this problem is the "Political Parties", and the author attempted to show and prove the direct link to bad governance to political party based governments. Therefore, the author's attempt here is to justify the points through sound arguments and on the basis of evidence that is available on hand.

\section{The Constitution as a Foundation}

Since the constitution is important for our government as a guiding force, it is therefore important to analyze this document to determine what guidance is there for us to achieve good governance in Bangladesh and what tools and mechanism is advised. This a readily available document but not widely read and very much neglected by the political 
party members, as a result we notice random violations once in a while in the daily politics making local news headlines often.

The constitution is a very simple to read document and the concepts are quite clear and straightforward. The preamble of the Constitution of Bangladesh begins with the proclamation of independence to establish the independent, sovereign People's Republic of Bangladesh; pledging that the high ideals of absolute trust and faith in the Almighty Allah, nationalism, democracy and socialism meaning economic and social justice shall be fundamental principles of the Constitution.

The fundamental aim of the State is to realize through the democratic process to socialist society, free from exploitation-a society in which the rule of law, fundamental human rights and freedom, equality and justice, political, economic and social, will be secured for all citizens and affirming that it is our sacred duty to safeguard, protect and defend this Constitution and to maintain its supremacy as the embodiment of the will of the people of Bangladesh so that we may prosper in freedom and may make our full contribution towards international peace and co-operation in keeping with the progressive aspirations of mankind.

Although all are written in fine prints and the constitution has been there in vogue since 1972, but as a citizen of the country this is the first time researcher read the document. In other words, our educational, political and social systems do not give our citizens and students to familiarize themselves with this valuable document at any stage of their academic life; whereas, in reality, this constitution is the prime source of guidance for leading the nation. It is a duty of every citizen to know what is in the constitution. Unaware citizens are unable to monitor the activities of a political party based government.

Fortunately, the researcher for the sake of thesis, reading of the constitution was taken up voluntarily. For clarity, let us review some of the passages from the constitution to understand the importance of this document and what it really contains.

\section{“21. Duties of citizens and of public servants.}

(1) It is the duty of every citizen to observe the Constitution and the laws, to maintain discipline, to perform public duties and to protect public property.

(2) Every person in the service of the Republic has a duty to strive at all times to serve the people..."

\section{"Supremacy of the Constitution.}

(1) All powers in the Republic belong to the people, and their exercise on behalf of the people shall be effected only under, and by the authority of, this Constitution.

(2) This Constitution is, as the solemn expression of the will of the people, the supreme law

of the Republic, and if any other law is inconsistent with this Constitution and other law

shall, to the extent of the inconsistency, be void."

From the above passages we can see that the constitution is regarded as the source of laws and the civil servants are instructed to strive to serve the people. The constitution acknowledges that the people (which include the politicians) are the source of all powers in a republic through solemn expression of the will of people. And any contradictions with the constitution are void and not to be tolerated.

Strangely enough, the existence of this foundational document is little known to the citizens and is kept hidden by not promoting the document and the message in it. Even many members of the rank and file of the government are no better than the common citizens as they too do not know what is in the constitution for the same reason as they too are the product of the same educational system. They run the government without knowing the constitution. It says further -

\section{"11. Democracy and human rights.}

\section{The Republic shall be a democracy in which fundamental human rights and freedoms and}

respect for the dignity and worth of the human person shall be guaranteed, and in which effective participation by the people through their elected representatives in administration at all levels shall be ensured..."

Unfortunately, the process of electing the representatives in the administration is questionable as the people elected do not always represent the people's desires and expectation at all levels as it is hoped for in the constitution. As a result, fundamental human rights, freedom and respect of the human person are not properly upheld. The people in power no longer consider themselves as the "representatives" of the people, rather they begin to think and act like owners of the people and the government resources. 
The constitution covers and addresses the areas of exploitation of general workers, provision of basic necessities, right to guaranteed employment, right to reasonable rest, right to social security, etc. But the ruling power in the successive governments seem to hide all these matters from the citizenry as if they do not want the citizens to know what their government is obligated to do and what they do instead. Is it not the political party based government that deprives the citizens of knowing their rights and duties towards their nation so that they could take advantage of citizen's ignorance? Otherwise, why are we not introduced to the constitution at our educational institutions during our school years?

According to Sami (Note 1), the constitution of Bangladesh provides for a parliamentary system of government with a unicameral legislature on a modified Westminster model (i.e., the British model). The members of the legislature (the Jatiyo Sangsad or the National Parliament) - are elected by universal adult suffrage. A member who the President feels commands the confidence of the majority in the parliament is invited to be the Prime Minister. The cabinet is headed by the Prime Minister who selects the ministers to be appointed by the President. The President is the head of the state and 'executive actions' of the state are taken in 'the name of the President'. But 'all executive powers' are vested in the Prime Minister. The constitution provides for a powerful and strong Prime Minister and the presidency is largely a ceremonial office. In the exercise of 'all his functions' except for the appointment of the Prime Minister and the Chief Justice of the Supreme Court, the President is obliged to act in accordance with the 'advice of the Prime Minister'. The President can not dismiss the Prime Minister; he does not have the powers to dissolve the parliament, except on the advice the Prime Minister. The President is the Supreme Commander of the Armed Forces. He also has the prerogative of mercy and can grant pardon, remit, suspend or commute any sentence. In these areas too he acts on the advice of the Prime Minister.

President's service is limited to two five year terms, but in case of the Prime Minister (PM) there is no limit to service, whereas the Prime Minister is more powerful than the President. Therefore, the PM ought to be a person of dignity and honor to be able to ensure good governance. But unfortunately, no qualifying criteria are laid down in the constitution for this post.

\section{The Structure of Government of Bangladesh (GoB)}

Every modern state or a nation has a government. A state is a politically unified people occupying a definite territory. The elements of the State are: Population; Territory; Government; and Sovereignty.

Government is the political direction and control exercised over the actions of the members, citizens, or inhabitants of communities, societies, and states; direction of the affairs of a state, community, etc. Government is necessary to the existence of civilized society. Without government the people will be just in a situation of a babel with no cohesion and means of collective action. Every modern state or a nation has a government. A state is a politically unified people occupying a definite territory.

The government of Bangladesh is setup following the western model of democracy. Modern government may broadly be classified into two types: Despotic and Democratic. Bangladesh is a democratic government with a Federal Parliamentary system under the dominance of the Prime Minister. However, the practice of this parliamentary democracy is questionable in Bangladesh as the so called "checks and balance" is next to nil in a political party based government as we will see as our discussion progresses.

The Legislature, Judiciary and the Executive are the three major power structures in Bangladesh government system. They are independent from one another and supposed to function independently without any political influence. But in reality we find a lot of interferences by the political party based governments in these governmental organs influencing the decisions and policies by political interest groups.

Similarly, in all the power organs of the government is influenced by the political groups taking advantage of the system exploiting the national resources to their advantage. The so called "Separation of Power" doesn't really work in Bangladesh as the appointments at the top levels are given by the party in power positioning the candidates of their likings as we have seen and discussed earlier.

Discussion on different power organs of the government is done below to understand how they were meant to work and what the situation actually is. The comparison of "theory and practice" will continue throughout this paper.

The theoretical diagram (Figure 1) gives us a neat image of the governance, but the reality is every sector of the power separations are influenced by the political party in power. No matter which party comes into power the scenario is the same.

Since the Ministers of each ministry are appointed by the political government in power, they tend to empower their best men in political connection regardless of their background and qualifications. All the high level appointments like the Chief Justice of the Supreme Court as done on political influence. Therefore, neutrality of the government is grossly compromised from the very beginning of the governmental setup after each election by the winning party without any exception. 
The lower level elections (i.e., Parishad, Upazila, etc.) are also largely influenced by the government in power favoring their own party member so that they get to get elected. The purpose behind this is to have a group of people in the government who are like minded and who would not oppose to any decisions the government makes regarding policies and developments. Under this setup, all decisions taken and passed by the government in power would look like democratic and as if they are supported by the people; whereas in actuality it is done by their closed knit network.

The overwhelming power control from the top to bottom disallows the middle bureaucrats to function independently and neutrally as they were supposed to. Moreover, to minimize resistance at the bureaucratic level the civil service recruitments are also politicized favoring party supporting candidates to come and work for the government; thus destroying the core concept of checks and balances in the government organs. These gross manipulations of power gives the party based government a supreme authority in every sector totally unchallenged by anyone. Even the opposition political parties become victim to this power setup and fail to operate democratically and cannot raise voice of any opposition. Now the scenario is such that even in a redefined state system the matter is unresolved where the Local Government, Private Sector and the Civil Societies are considered active partners in power checks and balances.

The local governments are mostly elected under the favored umbrella of the political party in power. Similarly, the private sector people are also greatly influenced by the political parties as many development projects done by the government is used as a bait to keep the business people under their dominance. It is very common in Bangladesh to see the business people belonging to political party influence taking the major share of the tender based development project allocations. In return, they are loyal to the political parties in power by offering generous donations and handouts at the time of elections and power struggle. This is how the looting of the state takes place. Finally, the Civil Societies are the only opposing group that remains in a position to oppose the government, but they are so small compared to the whole picture that they hardly have any impact in any decision making process.

\subsection{The Executive}

Part IV of the Constitution deals with "The Executive" where the powers and duties of the President, Prime Minister and Ministers are outlined (Figure 2). One point worth analyzing that in the Constitution, the masculine gender is used for the President and the Prime Minister, which is considered a "sexist expression" today but it was not in those days. The masculine expressions are shown in the passage below quoted from the constitution with an emphasis by the author

\section{"48. The President}

(1) There shall be a President of Bangladesh who shall be elected by members of Parliament in accordance with law.

(2) The President shall as Head of State, take precedence over all other persons in the State, and shall exercise the powers and perform the duties conferred and imposed on him by this Constitution and by any other law...

(4) A person shall not be qualified for election as President if $\underline{\mathbf{h e}}$ -

1. is less than thirty-five years of age; or...

\section{Tenure of office of Prime Minister}

\section{(1) The office of the Prime Minister shall be vacant -}

\section{1. if he resigns from office at any time by placing his resignation in the hands of the President; or}

\section{2. if he ceases to be a member of Parliament..."}

In other words, a female candidate is barred from being the President and Prime Minister of Bangladesh. Therefore, Khaleda Zia and Sheikh Hasina are illegal Prime Ministers and unconstitutional. In order to legitimize their presence in the government we must rewrite the constitution and neutralize the "sexist expressions". When the constitution was written the word "he" meant a male and "she" meant a female. And during those days no one anticipated that Bangladesh would ever have a female President or Prime Minister. Therefore, it is no mistake from the part of the authors of the constitution. They acted upon what was prevalent and acceptable in those days. Only in our modern times due to power sharing struggle between the male and female, we are facing problems with these words when dealing with women empowerment. Traditionally, women were seen as the home makers not competing with men in power struggle. Eliminating the gender based terms would not eliminate the universal truth and natural biological differences between a man and a woman.

The President is the supreme leader the Executive organ, but still according to the constitution the PM enjoys most of the power and is allowed to act in reference to the President if needed. The President on the other hand does not normally take any decision without consulting with the PM. Having so much of power for a select position that normally comes from a political background is a question of debate, which in turn selects or recommends other ministers in the Executive organ. The process leaves ample room for the political parties to position the people of their 
liking without being challenged. It is a serious blow to accomplishing a government with expected checks and balance in power.

\subsection{The Judiciary}

Part VI of the Constitution explains how the Judiciary should be setup. The diagram (Figure 3) briefly describes the structure of judiciary and it functions. The constitution envisages the separation of the judiciary from other organs and this is important to make a nation functional. The clause no. 22 of the constitution sums this as -

\section{Separation of Judiciary from the executive.}

The State shall ensure the separation of the judiciary from the executive organs of the State."

The past successive governments have demonstrated how the political party-based governments ignored this constitutional mandate and openly violated it without any opposition. Only during the Care Taker Government (CTG) the judiciary has again been separated from the influences of the other organs.

"The notion of separate and independent judiciary is one of the cornerstones of our Constitution. The separation of judiciary from the executive became finally operative from 1st November, 2007 when care-taker government formulated relevant rules and made amendment to the Code of Criminal Procedure (Amendment) Ordinance, 2007 is a response to apex court's twelve directives in the historic Masdar Hossain case. The implementation of separation of judiciary is fulfillment of a constitutional obligation that was a long overdue and is largely seen as outcome of our judiciary's proactive stand as successive political governments failed to realise this much needed constitutional mandate..." (Note 2).

This example shows how vulnerable we are as a nation where we are not even aware of the governmental activities and how they manipulate the citizens in the name of 'democracy'. The political governments always try to keep all the power control to themselves for easy manipulations without being subjected to any suspicion. For instance, the Chief Justice is an appointed position by the elected government, which is one of the steps to control the Judiciary indirectly. There is no guarantee that the appointed person would not be politically biased and be neutral. Through these positioning in the power structure the political government manages to give a blind eye to the constitution knowing very well the common citizens are ignorant about the constitution and their nominated Chief Justice is there to shield them. This message is reflected on the quotation below:

"The existence of a judicial system as the ultimate interpreter of the Constitution and the Law is an indispensable feature of a democracy governed by Rule of Law and not by Rule of Power. Judiciary, therefore, operates through Rule of Law for protecting legal and Fundamental Rights...It is neither the Cabinet nor the party in power but the uniform policy expressed in form of well deliberated laws and regulations made in a transparent manner should decide the issue in resolving those conflicting interests so that the entire community can pursue a common goal, despite their competing interests and values. The only safeguard for democracy is therefore the Rule of Law. It is the judiciary which is the final arbiter in enforcing the Rule of Law. When the government of the day tends to break or bend the law breaking its oath, causing imbalance in the system of governance. If the executive and the political power wants to wield its absolute power, it can push it as far as it can go by neutralizing the judiciary through allurement or intimidation or packing the court with nominees of one's own choice. Once they are allowed to do so this becomes not only the end of democracy but also likely to result in the break down of all institutions leading the country towards a chaos and anarchy." (Note 3).

\subsection{The Legislature}

By definition, the Legislature (Figure 4) is deliberative bodies of persons, usually elective, who are empowered to make, change, or repeal the laws of a country or state. It is the branch of government having the power to make laws, as distinguished from the executive and judicial branches of government. This is the hub of the political majority where most of the positions are held by the political party selections disguised in elections.

The Parliament is one of the important components of the legislating body in the government. The Constitution says the followings about the Parliament:

\section{“65. Establishment of Parliament}

(1) There shall be a Parliament for Bangladesh (to be known as the House of the Nation) in which subject to the provisions of this Constitution, shall be vested the legislative powers of the Republic:Provided that nothing in this clause shall prevent Parliament from delegating to any person or authority, by Act of Parliament, power to make orders, rules, regulations, bye-laws or other instruments having legislative effect.

(2) Parliament shall consist of three hundred members to be elected in accordance with law from single territorial constituencies by direct election and, for so long as clause (3) is effective, the members provided for in that clause; the member shall be designated as Members of Parliament. 
(3) Until the dissolution of Parliament occurring next after the expiration of the period of ten years beginning from the date of the first meeting of the Parliament next after the Parliament in existence at the time of the commencement of the Constitution (Fourteenth Amendment) Act, 2004, there shall be reserved forty five seats exclusively for women members and they will be elected by the aforesaid members in accordance with law on the basis of procedure of proportional representation in the Parliament through single transferable vote :Provided, that nothing in this clause shall be deemed to prevent a woman from being elected to any of the seats provided for in clause (2) of this article.

\section{(4) The seat of Parliament shall be in the capital."}

Since this is the main power hub in the government, a fierce competition of power struggle between the political parties is witnessed at this phase of the election. The political government in power tries their best to remain in power by hook or by crook. A similar situation was witnessed during the end of last political tenure where the power struggle between the parties became so immense that the Armed Forces had to intervene to install the CTG. Eventually, a relatively fair election was held under the CTG in 2008, but the result was somewhat disappointing, it was the Awami League (AL) that came to power with a majority in the parliament taking up almost 250 seats out of 300 ! This means, AL will always be the majority there free to do pretty much anything; and this is not desirable in a democratic scenario. Because, making laws (Figure 5) is an area of the legislature is fulfilled through the parliament (Figure 6). Therefore, any negative influence would have dire consequences for the nation.

It is important to evaluate the laws that were passed during the political party based governments to see how many of them are at par with the constitution and how many of them are violated. But the question is, if the governments is not balanced, and if no one is there to cross check it then who is going to do it?

\subsection{The Ministry and the Bureaucracy}

A Constitutional Body is there to ensure the functionality of the constitution and to protect it from any violations. But what we have seen in the past governments that they are neutralized through politicization by installing their politically influenced employees who give a blind eye to the constitutional violations by the government. During the CTG we have seen that the government tried hard and soul to empower the Election Commission as an independent entity the way it should be under which the election was finally held.

Similar situation was noticed at the Bangladesh Public Service Commission (BPSC) where civil service recruitment was put on hold for unfair recruitment processes on political influence. In a class room discussion meeting with the Chairman of the BPSC revealed that how notorious the government could be at times to force them to give in into their wishes under unfair pressures.

The Bureaucratic structure shown in figure 7 shows the hierarchy and chain of command. This chain of command is pretty much ineffective if the people of political influence are positioned there. Among the political group even if there are some neutral officers, they would not be allowed to function independently. In other words, good and fair officers would be forced to bow down to the political will and influence with an option to face consequences otherwise.

\section{Possible Solutions and Recommendations}

The objective of this paper is not just to talk about the problems, but also to seek out solutions. Focusing on and considering the present scenario of Bangladesh, we now find ourselves in a position where we are no longer sure which path to choose. We have pretty much tried out all the known political systems and have failed miserably with all of them. On the other hand, we do not have much time to invent something absolutely new either. Instead, what we can do is identify the major problems and modify or patch here and there to get our country up and running with a democratic government that would function properly, the way we want it. Some such clues are discussed below.

\subsection{Democracy and the Political Parties}

"Politics" today is just a business. In this business, one just uses the connections through abuse of power to achieve one's goal. Ethics and morality are underrated. As a result we witness the reality of tremendous decline of our ethics and morality in our social, corporate and civic life.

Our policy makers are no longer in a position to offer and maintain a good government as they themselves is no longer good. Therefore, we are now dreaming about "Good Governance" without any clue on how to achieve it. In most cases, we talk about good governance but we do not really mean it or want it. Because a notion has now developed in our minds that "goodness" does not pay. The reason for this change in our mindset is mainly due to absence of "reward and recognition" for goodness and fairness in our performance and absence of proper accountability toward the criminal activities. The famous saying of Martin Luther King Jr. (Note 4)., "Injustice anywhere is a threat to justice everywhere" is a blatant truth one can realize and conclude upon. In absence of justice, injustice is now prevailing everywhere. The local newspapers are reporting such news on a daily basis.

We have become so greedy that we do not mind selling our values and morals for a cheap price. We have sacrificed our principles and personalities for material gain hoping to live better. Forgetting totally that none of it would remain if we 
lose our precious independence and freedom. What good is wealth when there is famine and starvation all around? How well off are the crooks and criminals who so dedicatedly used their mind and soul for illegal hoarding of wealth? What good is their wealth to them now when they are locked up in jails?

Good governance is not something that could be done quickly as we see in a magic. It takes a lot to achieve the objectives. It takes strong patriotism. This is a realistic dream that could only be fulfilled if certain conditions are met. "Goodness" is a primary requirement before anything good can happen. If we are untrue to ourselves then we are just faking our intentions. Thus the result is "hypocrisy".

Nothing good can be expected out of a bunch of fouls. Their greed has led them to be subservient to foreign preys. We make unfair deals with foreign subjects without even understanding the consequences. Let us take Niko incident for example, where our nation ended up in major loss of natural gas resources for their inexperienced technical faults.

Where do they expect to go when their freedom is curtailed? What good is freedom if we can't do anything? Are they planning to be "refugees" and seek refuge and shelter in a foreign land living like a traitor betraying his or her own nation?

It is now evident that the political parties in Bangladesh are motivated by greed and lust for power and nothing else. Their prime objectives are ascending to power by hook or by crook and then loot the nation left and right. And this process has been going on for decades. According to Choudhury (Note 5), silent majority reckon that our politicians' culture of corruption mainly imprison vast majority of our people into poverty. Our maverick politicians preach moral and democratic values; constantly speak for greater rights for ethnic and religious minorities. They also speak about protecting human rights, reducing corruption and increasing the quality of governance, yet they practice antithesis of these values. In public speeches, they call on the people to practice benevolence, justice and brotherhood, yet they routinely violate these ideals themselves. Political parties are unused to the idea of sharing power and working together.

Following quote from a letter of a fellow citizen by the name Ekram Belal was published on the Daily Star on February 13,2008 that reflects a dire concern,

"My worry is one of Newton's law of physics which is also applicable to our corrupt politicians and the democratically elected governments. Forces of change will be gone with the departure of this current CTG and the evil forces of inertia will be back and will try to take the country and run it their old way..."

While doing literature review for this thesis work, the author came across with another good article written by Dr. Kamal Hossain (Note 6) under the title "Making democracy work: What we need to do", where he depicted the ugly picture of the political party based democratic system. He admits that we have bitter experiences of how the fruits of victory of our struggle have been lost due to the selfish pursuit of power by the predators. For people to become empowered, and to remain empowered, and to enjoy the fruits of victory, institutions need to be built, and checks and balances established in order to prevent usurpation of power by the predators, leading to disempowerment of people and their continuing dependence. A free and fair election is essential if we are to enable our people to choose honest and competent representatives who would genuinely represent them. But elections alone cannot ensure a working democracy, unless democratic institutions are strengthened and function effectively. A democratic culture enabling active participation by people, tolerance and mutual respect, must be nurtured. Candidates who are put forward by large parties, which are afflicted by the practice of selling nominations to corrupt persons, who see their election to public office as an investment, through which to earn huge dividends. They showed little interest in people's concerns, or in the strengthening or proper functioning of democratic institutions.

The systemic crisis of development of a working democracy has been caused by the injection into politics of arms, money and extremism, thus making politics sick. Sick politics did not feel the need to retain the confidence of the people by fulfilling election promises. Instead they manipulated elections with money and armed groups as reported in the local newspapers, even co-opting election officials and law-enforcement agencies. Political parties became centralized and their process of nomination of candidates degenerated into a form of auction or selling of nominations to the highest bidder. Potential candidates were questioned not about their qualifications or how they were equipped to serve the people but on how much money they could spend in the elections. This is how people became disempowered and growth of democracy was stunted. Political patronage of mafias made violence endemic. Armed cadres imposing their reign of terror in different locations became another ugly symptom of sick politics. Mafia-like structures spread through the country and the word 'godfather' found its place in common parlance even in the countryside as small arms continued to proliferate, with the connivance and protection of powerful coteries.

The police were prevented from taking action against such protected armed cadres in campuses and other arenas, as they were compelled to enforce law in a partisan manner, harassing and persecuting the poor and vulnerable and the political opponents of the predators in power while extending impunity to their protégés. Land grabbers who enjoyed political patronage deployed police to forcibly occupy lands and also to evict poor slum dwellers who comprise some forty per cent of our capital city's population. 
The law-enforcing agencies were also misused by those who practiced sick politics to patronize and protect extremist elements. Acts of terrorism were routinely covered up, investigations delayed and effective law-enforcement obstructed. There can be no rule of law where there is selective enforcement of law and the injection of the virus of "dolliokoron" (meaning grouping) into national institutions responsible for law enforcement and national security.

Armed cadres and private bahinis (meaning forces) controlled by godfathers, patronized and protected by "political parties" strike at the root of democracy. Democracy cannot work, nor can the rule of law assure security of life, person or property, unless there is comprehensive de-commissioning and disbanding of private bahinis and armed cadres.

Parliament did not develop into a forum for debating and adopting national policies on major subjects, ranging from education and energy to industry and agriculture, nor did it exercise accountability. With a dysfunctional Parliament and a non-accountable government, social and economic change which was a basic national goal, remained neglected.

The time has come to abolish all political parties and ban all party based political activities in Bangladesh. We should accept and move forward with a new concept of democracy that is plain and simple. All we should care about is "One nation, one goal". Banning of political parties would resolve $80 \%$ of our political problems; the remaining $20 \%$ can be handled by amending the constitution to accommodate the new system.

In absence of political parties, there will be no political candidates. Therefore, there will be no need for any political elections for candidates. Chowdhury (Note 7) wrote in an important article with the title "Blueprint for democracy" appeared on the Daily Star on February 15, 2008 where he said that the success of democracy depends on various factors. Education is perhaps number one on the list; then comes human rights. This would include freedom of expression, right to information, tolerance for each other's philosophies, and rule of law. All these factors have to come together to bring success to democracy.

Having an elected parliament and a cabinet does not mean democracy. Democracy has to be established at every level. It is not possible to discuss and solve all problems in a national assembly or parliament. Some of them must be dealt with at local level. This is what we call "local government." Besides, the essence of democracy cannot be practiced by those who do not follow democratic principles within their own parties.

The civil service is not the government. In a democratic society, the government is elected by the people (government of the people, by the people, for the people), and the civil service provides support and assistance to the government in the implementation of policies.

The civil servants at local levels must provide service to local governments in the same way that the Bangladesh Secretariat at Dhaka provides the support service to the national government. In this article we shall discuss two issues -- democracy within political parties and democracy at local government level.

The events of 1/11 have taught us a lot. We do not want to go back there. God has given us an opportunity and we must make best use of it. We must achieve fundamental changes and put democracy on track so that it does not get derailed again.

It is true that there is no democracy within the political parties themselves and their activities. Therefore, how can they advocate 'democracy' when they do not practice it themselves? Thus Chowdhury continues saying,

"First, let us talk about reform in political parties. We do not want political parties to be headed by hereditary leaders. Let not political parties be used as family property... The parties must remain committed to resolving all matters through democratic means. Finally, they must also spell out as to who can or cannot contest an election. Any criminal record should automatically disqualify a person, and the person must also meet some minimum criteria in respect of age, education, etc.".

At this point, by disagreeing with Chowdhury here, the author likes to advocate for abolishing of all political party activities in Bangladesh. It is clear that the political parties are undemocratic; instead of hoping that they would become democratic and passing laws to make them or force them to behave let's just say 'no' to that failed concept. We have done enough experimentation with "democracy" already and it is just a waste of time and effort.

\subsection{The Proposed Model}

Considering the nature and situation of people of Bangladesh, the best workable solution would be a "Council Based Democratic System". It means that, instead of elected officials in the government all we need is a group or council of "experts" independently formed to head the respected ministry. For instance, "The Economic Council" will run and monitor the affairs of concerned governmental ministry. "The Agricultural Council" would look after the affairs of the Ministry of Agriculture, and so on.

The graduates of all the universities would automatically become members of the respective councils and they would have their own elected or mutually selected or nominated board members for a term, say five years. Non graduates or 
graduates of other disciplines who are interested in becoming a member could be allowed membership to ensure participation and contribution in the area.

The routine council sessions will be held at the parliament house in regular intervals and will be broadcasted through our media of all kinds, so that the members' at large or distant members could also participate in decision making process for the nation.

The idea is similar to the "Citizen Council" suggested below, but only better -

"To counter a single party or a powerful leader from monopolising power, a modified form of Athens Council may be in order. Besides voting for the candidates of different parties, a Citizen Council composed of prominent citizens may be formed. This will include civil society members -- academics, lawyers, journalists, business people, union members, and other citizens who want to contribute to public life..." (Note 8).

Under this system, there would be no need for wasteful nation wide elections, and all decisions would be taken in broad daylight through open sessions; meeting agendas and minutes and will be passed on to the concerned ministry for execution or implementation. Figure 8 shows a format of a Council Board that is recommended.

This system would not allow Tom, Dick and Harry to intervene in any democratic processes. Nor will they ever get a chance to hold positions for which they are not qualified. All things will be governed by experts in respective areas in a democratic way. All decisions will be taken on the basis for what is good for the nation. No personal interests would get preference at any point as a parliamentary system will be in place.

The good thing about his system is that the process would be constant and the vision of the nation will be long term and effective. There will be no chance for any interference in long term projects and national strategies, as there will be no change in government, ever. The whole nation will be focused into one single direction and follow a track smoothly without any distraction. This process will replace the Parliamentary Elections.

\subsection{The President}

We need a national leader or a president. The leader who would be representing the nation could be an elected one, elected by the citizens in open competition. The criterion will be to elect the best among the candidates based on his or her academics, personalities, and other competitive edge they hold and offer. This position could be for a five year term, but would not hold much power in reality. Because, in a council based democratic system, the country is actually run by the citizens behind the scene. A decision of the president would not be required. In fact, the country would function even if we do not have a president! But still, we should have one, who would be our ambassador to the world community.

\subsection{Presidential Election}

Every five year, there will a presidential election nationwide in an open competition among the interested and independent candidates whose candidature would be approved by the security council of the country after all background check and managed and organized by the Election Commission. This would prevent the crooks and criminals in becoming a candidate. It will be a daylong election day when the eligible voter citizens would cast their votes. The majority vote would bring the successful presidential candidate to take oath ceremoniously.

There will be no other national elections besides this presidential election. All other elections will be held internally within the council members of the respective councils.

\subsection{The National Security Council}

Under this setup the author suggest for existence of a National Security Council (NSC). An increasing threat of global terrorism as well as from home grown terrorists is now on the horizon that did not exist before. Recently we have witnessed one such incident at the Pilkhana Bangladesh Rifles (BDR) Head Quarters on 25 - 26 February 2009 where almost hundred military officers were murdered in a mutiny. On $29^{\text {th }}$ of May 2009 Prothom Alo reported on the first page that during the period of $2001-7$ about 1300 BDR soldiers were recruited under the political backing. Therefore, can we conclude that the mutiny at BDR was politically triggered to seek revenge on the officers who harassed the politicians during the CTG? If that is really the case, then we are all in tremendous hate crime and the whole country is in terrible danger.

Many countries are now adapting the concept of NSC. Bangladesh too needs to adopt one -

"It is argued that if some institutional structure like National Security Council consisting of civilian and military leaders is constituted, military leaders could have some say in the running of the state power and military officers would be less prone to take over political power directly...It must be mentioned here that General Ershad established a National Security Council consisting of a few senior ministers of his government and three chiefs of armed forces. But Ershad had no commitment to the cause of national security. Ershad's NSC atrophied and soon died...The defense of 
the country against direct and indirect international and national forces may be better managed by the establishment of civilian dominated NSC..." (Note 9).

It is recommended that the NSC is formed with the following leaders according to the protocol below:

1) The President.

2) Chairman, Co-chairman and the Secretary of the Defense Council

3) The Chiefs of the Armed Forces.

4) The Chiefs of the Law and Enforcement Agencies (i.e, BDR, RAB, Police, National Guard, CID, etc.)

\subsection{The Parliament}

The Parliament House will be used for regular National Council assemblies. There will be no more fixed or permanent parliamentary committees as we have today. A special committee will be formed at the time of National Council Sessions on ad hoc basis by the respective ministries holding the sessions. In other words, all the entry doors for crooks, criminals and ineligible candidates will be closed for good. Only the competent candidates with proven track records will take office. The President could preside over the meetings or sessions.

\subsection{The Local Government}

There will be no election at the local level. A government office will be there to handle all activities at the local level where all the citizen / voters living within that area will be members. Any member moving from one location to another must do so by notifying the local government office so that his or her membership could be transferred to new location or jurisdiction of his or her new residency. This way the mobility of a citizen could be tracked, which would eventually help the government in implementing social safety net programs effectively. Now that we have already created a national database of our citizens in order to prepare and issue the voter registration card (which is also our national ID card), through this mechanism the information on the database could be constantly updated.

On February 15, 2008 news appeared on the Daily Star newspaper on local government matter where the speakers at a view exchange meeting said that transparency, accountability and citizens' participation in different development works and in formulation of budgets have become essential for good local governance as well as poverty reduction. They also stressed that self-reliance is needed to strengthen local government and this becomes possible when citizens are sure of good returns. The views were exchanged at the meeting for sharing achievement of Sharique, a local governance program with Inter Cooperation of Care Bangladesh at Nanking Darbar Hall. Sharique program is helping union parishads manage public affairs in a more effective said several union parishad chairmen and members in a special discussion arranged for sharing their experience.

Citizens' participation at the local government level is crucial in national decision making process. Attempts have been made at the root level to motivate and encourage citizens to participate without much success. But in the newly proposed model citizens' participation is a must to run a government. According to standard rule of thumb, for a valid quorum, one third of the total members would be required to validate a meeting or session. Now here we are talking about direct democracy.

The concept of "Direct Democracy" is taking shape around the world. The author has come across with one such website that advocates this concept at http://www.freewebs.com/platoxxi/index.htm. It talks about the direct representation of the people through the use of modern technologies that would eliminate use of 'representatives' at the local level. We could make this idea a reality. The idea is not really new,

"In addition to challenges to traditional patterns of governance arising from globalization and from the power of networks, there is yet another set of challenges that would produce very different styles of governing. This collection of related challenges all endeavor to deinstitutionalize governance and to more directly involve citizens in making binding policy decisions. The assumption undergirding these ideas is that the public can - and more especially should - have more direct influence over decisions than they can exercise in respective democracy... to focus on citizens themselves as the principal source of governance." (Note10).

Let the people who knows and understands the issues deeply should be allowed to have their say in policy devising in the council meetings at the parliament. This is one of the ways to go for digital Bangladesh.

\section{Comparison of the Two Systems}

For simplicity, the author felt the necessity to compare the existing and the proposed systems of governance to get better understanding of the two models. Therefore, table 2 is a given below to understand the difference between the existing system and the proposed one.

\section{Conclusion}

One may wonder why a system based on the 'Council of Experts' is advocated. What is the big deal with 'experts'? To understand, we need to first understand what the experts do. 
Star Weekend Magazine published an article entitled, "Developing Bangladesh through Research" on January 11, 2008 where it is acknowledged that for a developing country research is probably the single-most important tool in keeping a pace with the rest of the world. It's certainly not the most glamorous work in the world, requiring hours of sifting through miles of data and information, making comparisons and coming to conclusions, but at the end of the day, without such research from as varying topics as agriculture, health and migration, all development work would simply fall apart. One organization that has been consistently doing this tedious, and often unrecognized, job for the last 50 years is Bangladesh Institute of Development Studies (BIDS). It is mandated to function as an agency for initiating and conducting study, research and dissemination of knowledge in the fields of economic development, population studies and human resources and other social issues related to planning for national development. BIDS serves as a conduit for dissemination of research findings through its library, publications, website and seminar programs, conducting training and workshops and generally engaging proactively with the broader national and international communities. BIDS researchers also directly contribute to formulation of development policies through participation in government committees and task forces. In short, BIDS serves as a resource centre for the community at large.

BIDS appears to be the 'one organization' that carries out research activities on real life issues faced by the nation. But ideally, not just BIDS, the higher learning institutions like the public and private universities were also supposed to carry out research activities and publish them in local and international journals for peer review and use that research outcome in national development. But in reality, we hardly see any research outcome from the teachers and researchers of our universities, which is reflected by Rahman (Note 11) when he said that unless we generate enough indigenous knowledge capital which is also globally competitive, it may be very difficult for us to face this onslaught of global policy intervention. This local knowledge generation has also to be further refined at a higher level called research. Research is one area which has been thoroughly neglected in Bangladesh. The universities in Bangladesh are producing too many artificially intelligent young persons who are not interested in questioning the world around them. They do not abstract theoretical ideas from the reality and apply the theory in explaining the reality.

Very few of our qualified academicians and researchers participate in international symposium, workshops, seminars and conferences. Part of the reason could be that not much of opportunities and financial help are offered in that area. Besides, under a political based government system most of the international participation invitations are passed to the party members who just attend those programs with an empty head and bring back nothing for the nation. They see those as an "opportunity for foreign trips" missing the actual point for the visits. In other words, under a political party based government system true and qualified people are left out of these opportunities, which is a matter of great shame and loss for the nation.

Many of the foreign $\mathrm{PhD}$ scholarships are given to civil servants where as they were mainly intended for the university teachers. $\mathrm{PhD}$ track is normally an academic track to prepare a academician or an educator to officially prepare for a research work that normally spans for anywhere from two years to six years attempting to contribute to knowledge in a area that has not been addressed before. It is a serious commitment and requires full focus and attention. Therefore, these scholarships should go to the college and university teachers who are appointed and hired to do research work and develop effective teaching methodologies.

A $\mathrm{PhD}$ degree would not make an administrator to perform better in civil service. However, if the civil servants are engaged in research and development works in a governmental college or institutes then they should go for PhD's to better prepare them in their research work.

A research takes time, energy and resources. If the country does not support or backup our potential researchers, then the interest would not develop in the minds of our promising citizens. The developed countries spend a huge amount of their financial budget in research activities. And that is how they maintain their competitive edge in the world competition not only resolving their own problem, but also the problems of other countries.

No one would understand and address our problems any better than we would. Therefore, it is important to engage our own researchers in resolving our own problems. A local consultant would be the best consultant. Rahman expresses the same view when he goes on saying that with changing economic and social conditions, the focus gradually moved to many areas relating to globalization, macroeconomic issues, agriculture and rural development, water resources management, poverty and inequality, food security, microcredit, health, nutrition, education, energy, environment, gender, empowerment, migration, urbanization and other development issues. BIDS with a Parliamentary Charter which gives it wide and effective autonomy in the choice of research issues can make important contribution to the national policy agenda. The research output of BIDS provides valuable input to the policy makers and development practitioners for designing appropriate development interventions. The contribution of BIDS to the country's development process, however, remains contingent upon the choice of relevant agenda and proper use of its research output by the end-users. The gap between research and policy making has historically remained quite significant in Bangladesh.

The idea is to spread the research activities under the control of all councils and ministries for various fields instead of centralizing it under BIDS alone. Different councils will publish their own journals (e.g., The National Journal of the 
Economic Council) consisting of the best research outcome that could be considered in the council sessions for policy making. We could use the information technology to make the research outcome available for the public to see and review them online. BIDS along with the Public Libraries and universities could play an important role of facilitating the researchers by arranging and supplying reference materials through their existing library facilities on membership basis.

This arrangement would eliminate any possibility of influence in research and idea generation. In absence of political influence, there will be no secret or unwanted interference.

G.M. Quader was a Member of the Parliament who wrote on the actual scenario of the political party based democracy system under the title "Dilemma of democracy" where he said that, since independence, the people of Bangladesh had always held the aspiration of practicing democracy. The country started with parliamentary or ministerial form, changed to presidential form, to one party rule, to extra-constitutional rule through proclamation of martial law, to multi-party presidential form again, to extra-constitutional rule through proclamation of martial law again and finally to parliamentary or ministerial form. National election for the 9th Parliament was scheduled for January 22, 2007, to be conducted under a caretaker government (CTG) formed for that purpose. But, before the election date, it became obvious to all that the BNP-led four party's alliance in power had set the stage for a manipulated election to come back to power through fraudulent practice. Nationwide protest continued under the leadership of the combined opposition parties (all parties other than parties in the ruling alliance in 8th Parliament), with widespread violence for stoppage of that election.

Ultimately, the armed forces had to intervene, and that election had to be postponed, on January 11, 2007. The question is, why, and under what circumstances, did democracy fail? Judging from different political activities during the period from 1991 till postponement of election for the 9th Parliament on January 11, 2007, it became obvious that there had been a continuous downslide of values in our political culture.

An ever-increasing gap was created between political parties and the people. Political parties, instead of becoming the people's property, became the property of an individual or a group of individuals. The parties, instead of working for the people, were devoted more towards personal and group interest, even in most cases at the cost of public interest.

In a way, it might have been termed as corporate culture in politics. Political parties took on the hue of a business enterprise, with ownership of a person or a group of persons. Offspring or family members could inherit the ownership of the party. The situation in some political parties was such that the ownership could be sold. Different positions, including policy-making positions, of a party could also be purchased.

Like a business house, the party used to be run by the party chief as chief executive, with the rank and file as employees. The aim of politics became financial profit. Winning an election by hook or by crook to go to power and earn money through corruption and by abusing official authority became the natural consequence of the said corporate political culture.

Power oriented politics led political parties to a rush for grabbing state power, where the interest of the people and future of the nation bore no consequence at all. All mechanisms for manipulation of election results by use of money, muscle, official authority, bribe, politicization of administration etc., became part of the game of politics. The other consequence was refusal to accept defeat in the election because of irregularity, as that was more or less there in almost all cases.

One of the prime causes for existence of corporate political culture in our political system is the election and, to be precise, the way it is conducted in Bangladesh. There are sufficient election laws, regulations, codes of conduct etc. for conduct of a free and fair election. But, unfortunately, in reality, there are no effective means for implementation of those laws. There exists enough scope to influence election results with use of money and muscle power.

The majority of the population is poor and still illiterate. Moreover, there are lapses in providing security to the lives and property of common people. This added to inefficiency, corruption, and partisan attitude of the conducting officials made it possible for people with big money and muscle power to snatch the result in their favor by influencing through fear and favor.

If a person having muscle power could earn enough money using the same, he could become a potential candidate with high prospect of success. So could corrupt businessmen and corrupt bureaucrats with sufficient money. Violent and corrupt criminals became the target for recruitment by the political parties, as they were good at wining elections.

When they were recruited in a party in key positions, they took control of the party in time. It was they who inducted corporate political culture in parties, with an aim to gain financial profit. Ascending to power is, for them, creation of scope to achieve that goal. These people never had any scruples, so they did not see reason not to use illegal or unethical means to win election for going to power. They also see no reason not to abuse state power, once acquired, to earn personal profit through corruption and irregularities. 
This new breed of so-called politicians may be good in winning elections, but lack background and education to perform as good parliamentarians. They could never be expected to perform in government positions to serve the people properly with honesty and dedication.

So, the dilemma of our democracy at the moment is that the person who manages to be elected to parliament is not fit to perform in parliament or in government. On the other hand, a person who is capable of becoming a good parliamentarian and could serve the government efficiently is not good at winning elections. To have sustainable practice of democracy associated with good governance a solution must be found to break the deadlock created by the said dilemma, points out Quader (Note 12).

The democratic systems we have today are actually a "deception" and are meant to cause fractions in a nation, not unify it. Besides, different countries have different kind of democratic systems anyway! So, we should have it our way.

"Bangladesh's political scene has been tumultuous since independence. Periods of democratic rule have been interrupted by coups, martial law, and states of emergency.

There is a proverb in Bangla which loosely translates into: If you have two Bengali's you will have three political parties. This is kind of evidenced in the existence of over 100 political parties. Most of these are small, fringe parties formed mostly by a small coterie of like minded intellectuals or politicians who usually have broken away from larger groupings..." (Source: http://www.virtualbangladesh.com/bd_politics.html).

The idea of "grouping" is fatal for us. Grouping divides and leads to conflicts. As a single nation of Bangladesh, we should do away with all the groupings and unite under a single philosophy, which is best for all of us.

The Awami League (AL) party has won the Members of Parliament (MP) elections overwhelmingly taking up almost 250 seats out of 300, which means there will be an imbalance in the Parliament as the opposition parties will have no power to exercise there anymore. The session quorum will not be affected and any decision taken by the majority vote by AL will pass even if the whole opposition walks out of the Parliament, which is not good.

We are already witnessing the power play of the AL government where they are attacking the opponent party members killing and looting their houses in the rage of revenge for the past incidents. We have also seen the attempt of the AL supporters to influence the local government elections. More and more power play will be seen almost in every sector of the government and business as the time passes. This is inevitable under a political party based government system.

It is very common to see the winning party when they ascend to power tries to nullify many decisions taken by the earlier government. This rivalry attitude in the political party based government takes the nation backward instead of taking it forward.

In order for Bangladesh to accommodate the suggested changes, the Constitution would have to be modified. A thorough exposure and propaganda of this concept would have to done to earn peoples support as this concept will face fierce resistance from the political parties. They would not want to accept this change. Some bold step may have to be taken to get this implemented as H. M. Ershad did. Sami (Note 13) reminds us by saying that in 1991, when the presidential system was discarded, it was incongruously decided to retain for the Prime Minister some executive powers and establishments of the Presidential system as well as some trappings of the presidency. Some of these measures were innovative creations of President Ershad to perpetuate his dictatorial strangle hold on the civil and military establishment at the expense of the powers of other ministries. Most of these are not compatible with the temperament of traditional parliamentary system and are unfriendly to the concept of joint cabinet responsibility and authority.

There have been calls for the "Review of the Constitution" by many. One such editorial was published by Rashid (Note 14) who said that Chapter IIA of the constitution, that envisages a non-party caretaker government between the elected outgoing and the incoming governments, was incorporated in the Constitution in 1996 because the political parties could not trust the ruling party to hold parliamentary elections.

The functions of the caretaker government are enumerated in Article 58D where, in case of necessity, the government can make policy decisions. Furthermore, since this caretaker government was installed under unusual circumstances during political turmoil, chaos and lawlessness, it has to fight against what the government has recently described as the 3 Ms -- Money, Muscle and Misuse of power. The Constitution had undergone 14 amendments as of today, and these amendments have changed the Constitution of 1972 so much that it has lost the substance, spirit and character of the Constitution of the founding fathers.

The first severe knocking-blow to the Constitution came in 1975 when the system of government was turned into presidential from parliamentary. This constitutional change from parliamentary to presidential, and making a one party-state, destroyed the fundamentals of the 1972 Constitution.

Successive military regimes under martial law had also amended constitutional provisions as they wished through Presidential Orders or Proclamations. The Constitution is based on certain expected assumptions and conduct from office holders. Those expectations had been totally ignored in practice in the past. The ruling party leaders did not 
interpret or use the provisions of the Constitution in good faith. The 37 years of governance has demonstrated the pitfalls and deficits of the provisions of the Constitution. Some of the amended provisions are totally against the democratic norms of the Constitution and need to be deleted. What is imperative is that provisions of the Constitution must be made explicitly clear, with checks and balances on the separation of powers among the organs of the state executive, legislative and judiciary.

Simply said, the government runs the administration, parliament enacts laws and judiciary interprets the laws. Each organ has its own limits of power enumerated under the constitution, and that is the essence of constitutional democracy in a Republic.

Everyone agrees that the present Constitution needs drastic revision in the light of our past experience, and should take into account the political, social and cultural environment of the country. A Constitution is not a "one size fits all" phenomenon, which can be transplanted in the country from another country. In this context, the setting up of a Constitution Review Commission calls for urgent attention for national interest.

Bangladesh simply does not meet the basic criteria for a political party based democratic system for many different reasons as discussed above. Therefore, this concept should be totally abandoned. To ensure Good Governance in Bangladesh, we must take the non-political party approach. The idea here is, if the echelon is cleaned and remains stable then the remaining branches would also enjoy a better outcome. Elimination of party based politics would yield multi-dimensional benefits for the country and its people as discussed above. The main objective is to give something useful and meaningful to the nation that could be seriously considered for implementation at a turmoil situation as we are facing today.

The author fears that Bangladesh is going to make the same mistake again if no new directions are shown. Therefore, this paper is intended to serve that purpose. Further research and a dissertation at the $\mathrm{PhD}$ level can be undertaken on this subject. But at the master degree level thesis the author could only have the liberty to venture up to this level. Finally, the author intends to end this thesis with a quote from Groucho Marx (Note 15) -

"Politics is the art of looking for trouble, finding it everywhere, diagnosing it incorrectly and applying the wrong remedies."

\section{References}

"ACC to probe 'graft in military"'. (2008). The Daily Star. February 15.

Anir Chowdhury. (2008). "E-Governance: Myth or reality for Bangladesh". The Daily Star 17th Anniversary Special Edition. February 18.

"Bangladesh should have own brand of democracy". (2008). The Daily Star. February 21.

Chowdhury, Fazlur R. (2008). "Blueprint for democracy”, The Daily Star, February 15.

"Citizens' participation stressed for good local governance". . (2008). The Daily Star. February 15.

Choudhury, Anam A. (2008). "Use and abuse of democracy", The Daily Star, April 5.

Elahi, Mahmood. (2008)."Learning from ancient Athens". The Daily Star. February 27.

Faruque, Dr. Abdullah Al \& Noman, ABM Abu. (2008)."Separation of judiciary: Opportunities and challenges", The Daily Star 17th Anniversary Special Edition. February 18.

Heeks, Richard. (2006). Implementing and Managing eGovernment, SAGE Publications., UK. pp 10, 21.

Husain, Sadaat. (2008). "Divergent statistics unhelpful to planning". The Daily Star 17th Anniversary Special Edition. February 17 .

Husain(2), Sadaat. (2008). "Recruitment at the top". Point Counterpoint. The Daily Star. December 6.

Hossain, Dr. Kamal. (2008). "Making democracy work: What we need to do". The Daily Star 17th Anniversary Special Edition. February 16.

Islam ,M. Amir-Ul. (2008). "Implementing Separation of Judiciary: Taking a close look at core issues". The Daily Star 17th Anniversary Special Edition. February 18.

Islam (2), Mohammad Shahidul. (2008). "Combat or perish." The Daily Star 17th Anniversary Special Edition. February 18.

Maniruzzaman, Talukder. (2008). "National Security Council for Bangladesh?". The Daily Star 17th Anniversary Special Edition. February 16.

Mohsin, Prof Selina. (2008). "Reforming the civil service", The Daily Star 17th Anniversary Special Edition. February 16. 
Pierre, Jon and Peters, B.Guy. (2000). Governance, Politics and the State. Macmillan Press Ltd. UK. pp 137.

Quader. G.M. (2008). "Dilemma of democracy”. The Daily Star. January 11.

Rahman, Nader. (2007). “A Price too High to Pay”. Star Weekend Magazine, May 9.

Rahman (2), Dr. Atiur. (2008). "How good is consultancy dominated research?". The Daily Star 17th Anniversary Special Edition. February 18.

Rashid, Harun ur. (2008). "Review of the Constitution". The Daily Star, June 18.

Sobhan, Sanjida. (2008). "RTI Act: Challenges for Implementation". The Daily Star $-17^{\text {th }}$ Anniversary Special. February 18.

Sami , C M Shafi. (2008). "Dispersal of power for check and balance". The Daily Star 17th Anniversary Special Edition. February 16.

The Constitution of Bangladesh. (1972).

Taifur, SASM. (2006). SICT's Steps Towards Good Governance Through ICT's, Ministry of Planning, GOB, July. pp. iii, 16.

"Virtual Bangladesh : Politics." Virtual Bangladesh. $\quad$ October 30, 2006. http://www.virtualbangladesh.com/bd_politics.html.

\section{Notes}

Note 1. C M Shafi Sami, The author is former adviser, caretaker government and former secretary and ambassador.

Note 2. Dr. Abdullah Al Faruque \& ABM Abu Noman, Authors are members of faculty of law, University of Chittagong.

Note 3. M. Amir-Ul Islam, The author is senior advocate Bangladesh Supreme Court.

Note 4. Martin Luther King, Jr. (January 15, 1929 - April 4, 1968) was an American clergyman, activist and prominent leader in the African-American civil rights movement.

Note 5. Anam A Choudhury is a former investment banker.

Note 6. Dr. Kamal Hossain is President Gonoforum and legal luminiary.

Note 7. Fazlur R. Chowdhury is a freelance contributor to The Daily Star.

Note 8. Mahmood Elahi is a freelance contributor to The Daily Star.

Note 9. Talukder Maniruzzaman, the author is National Professor specializing in military and security affairs.

Note 10. Pierre, Jon and Peters, B.Guy. Governance, Politics and the State. Macmillan Press Ltd. UK. 2000. 157.

Note 11. Dr. Atiur Rahman, the writer is Professor, Department of Development Studies, University of Dhaka, and Chairman, Unnayan Shamannay.

Note 12. G.M. Quader is a former Member of Parliament.

Note 13. C M Shafi Sami, the author is former adviser, caretaker government and former secretary and ambassador.

Note 14. Barrister Harun ur Rashid is a former Bangladesh Ambassador to the UN, Geneva.

Note 15. Julius Henry "Groucho" Marx (October 2, 1891 - August 19, 1977) was a Jewish American comedian and film star famed as a master of wit.

Table 1. Position equivalency.

\begin{tabular}{|l|l|l|}
\hline Sl.\# & New position & Equivalent to \\
\hline 1 & Council Chairman & Minister \\
\hline 2 & Co-Chairman & Deputy Minister \\
\hline 3 & Secretary & Secretary of the Ministry \\
\hline 4 & Directors & Member of Parliament \\
\hline
\end{tabular}


Table 2. The comparison list.

\begin{tabular}{|c|c|c|}
\hline Sl.\# & Present & Proposed \\
\hline 1 & There is a president with limited power. & Here too will be a president with limited powers. \\
\hline 2 & There is a powerful prime minister & Prime minister not required. \\
\hline 3 & There are bunch of "ministers" for different ministries. & $\begin{array}{l}\text { There will be "Chairmen" (in plural terms) for different councils } \\
\text { heading a ministry. }\end{array}$ \\
\hline 4 & $\begin{array}{l}\text { There is a presidential election and the prime minister is } \\
\text { appointed by the president. }\end{array}$ & $\begin{array}{l}\text { There will a presidential election and there will also be independent } \\
\text { council elections for chairmanship and formation of Council Boards.. }\end{array}$ \\
\hline 5 & $\begin{array}{l}\text { The president is the Chancellor of all the universities of } \\
\text { Bangladesh. }\end{array}$ & $\begin{array}{l}\text { There will be Chancellors for each university. The president would not } \\
\text { be the Chancellor anymore. }\end{array}$ \\
\hline 6 & $\begin{array}{l}\text { The ministers are appointed by the prime ministers who are not } \\
\text { necessarily qualified to hold the positions }\end{array}$ & $\begin{array}{l}\text { Here the chairman will be of the same discipline and would be } \\
\text { pre-qualified by his council members with complete background check } \\
\text { by the security council. }\end{array}$ \\
\hline 7 & $\begin{array}{l}\text { The chairmen of the local government are selected through } \\
\text { elections. }\end{array}$ & There will be no election or chairman at the local government level. \\
\hline 8 & The civil servants enjoy a sense of permanency in job. & $\begin{array}{l}\text { No such notion will be there. Incompetents will be removed from } \\
\text { positions. }\end{array}$ \\
\hline 10 & There are foreign interferences through political parties. & There won't be any. All the people would develop a patriotic feeling. \\
\hline 11 & $\begin{array}{l}\text { There is open and hidden competition among the political } \\
\text { parties to gain and stay in power. }\end{array}$ & $\begin{array}{l}\text { There will be no such "power" to fight for as all citizens would } \\
\text { participate in political and democratic process at will. }\end{array}$ \\
\hline 12 & $\begin{array}{l}\text { Bangladeshis shows disunity on political grounds due to their } \\
\text { personal affiliations with a party even in foreign lands. }\end{array}$ & $\begin{array}{l}\text { Bangladeshis will stay united regardless of their background in foreign } \\
\text { lands upholding the dignity and good image of the nation. }\end{array}$ \\
\hline 13 & $\begin{array}{l}\text { Every five year before the new election, a caretaker government } \\
\text { intervenes and cleans the mess of the earlier party government. }\end{array}$ & $\begin{array}{l}\text { There will be no need for the caretaker government to intervene as } \\
\text { only the president will change in every five year term through national } \\
\text { elections. }\end{array}$ \\
\hline 14 & $\begin{array}{l}\text { When things deteriorate badly politically, the military jumps in } \\
\text { to take control and declare martial laws. }\end{array}$ & $\begin{array}{l}\text { Since the system will be run by the citizens without any political party } \\
\text { influence, our military would not have go out of their way to enter into } \\
\text { political rescue. }\end{array}$ \\
\hline 15 & $\begin{array}{l}\text { There is uncontrolled corruption without any scope for any } \\
\text { check to it. Political parties use their power and influence to } \\
\text { rescue the criminals belonging to their parties. }\end{array}$ & $\begin{array}{l}\text { There will be no corruption as all appointments will be on the basis of } \\
\text { fair competition and on merit. Besides, there will be no permanency of } \\
\text { jobs anymore. There will be no political party influence to rescue the } \\
\text { criminals. }\end{array}$ \\
\hline 16 & $\begin{array}{l}\text { Due to five year term of party based government, many long } \\
\text { term projects and plans go wasted when a new government } \\
\text { takes over resulting in financial loses when such a project is } \\
\text { halted or cancelled. }\end{array}$ & $\begin{array}{l}\text { Since there will be no political motive at any time on any decision } \\
\text { taken at the council by the council members; therefore, all projects } \\
\text { would get implemented and completed even when the chairman or the } \\
\text { board members changes. }\end{array}$ \\
\hline
\end{tabular}

\section{Separation of Power: Bangladesh}

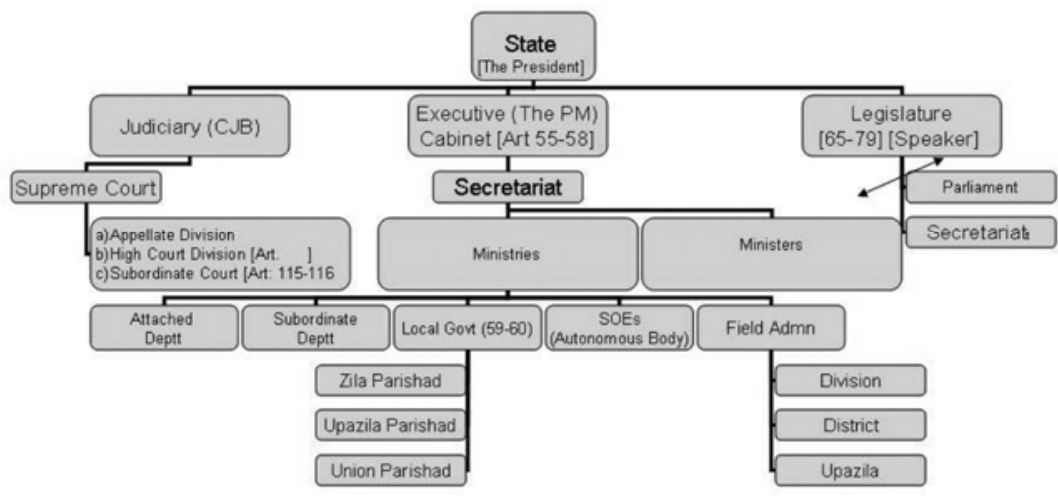

Figure 1. Separation of power between the three organs. 


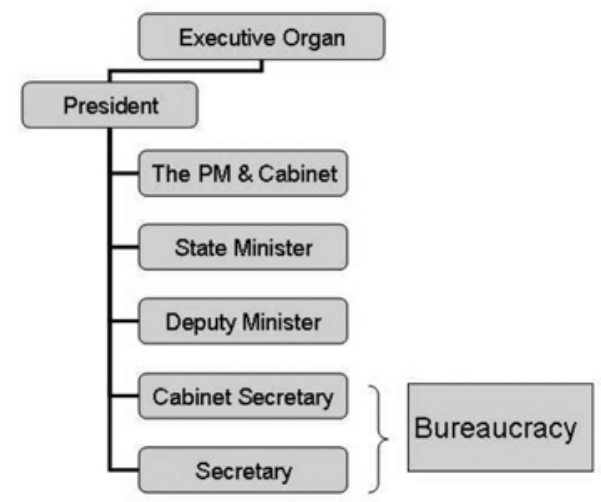

\section{Executive Organ}

Figure 2. The Executive Body.

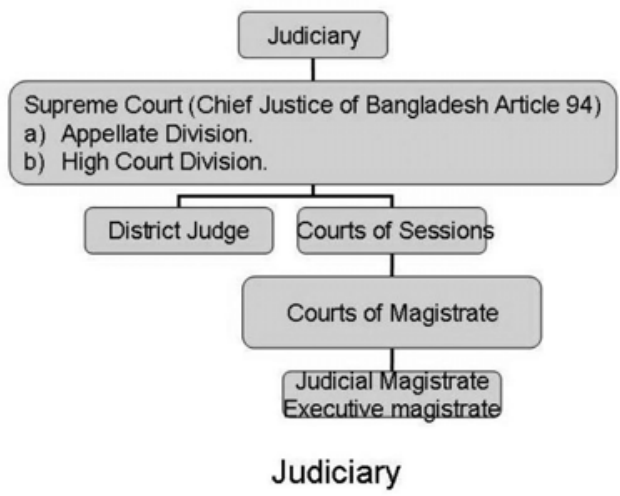

Figure 3 . The Judiciary.

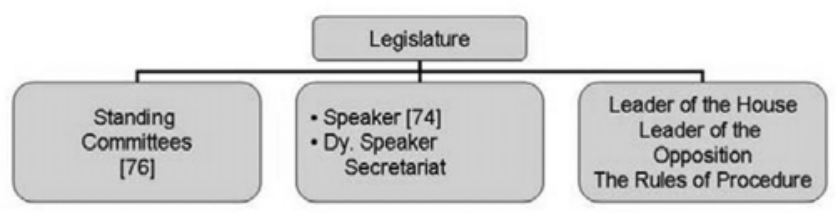

Figure 4. The Legislature.

Bill [80]

Finance Bill [81]

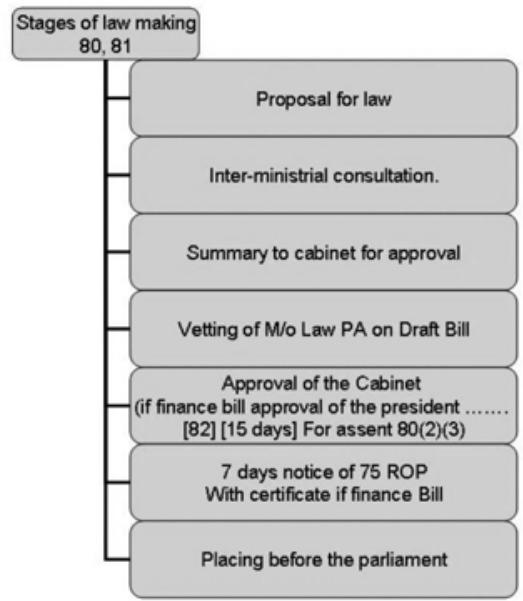

Figure 5. The law making process. 


\section{Constitutional Body}

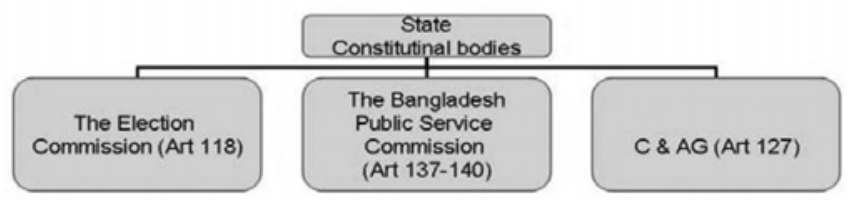

Figure 6. The Constitutional Bodies.

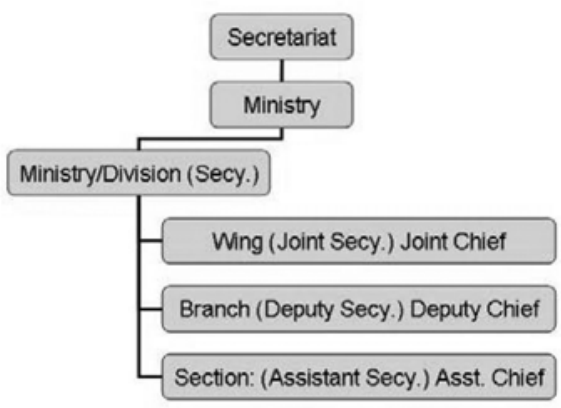

Figure 7. The Bureaucratic structure.

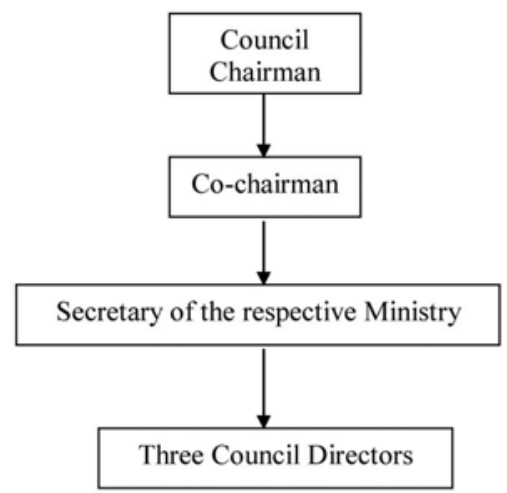

Figure 8. Proposed Council Structure. 